\title{
Recombinants within the Tyrosine Kinase Region of v-abl and v-src Identify a v-abl Segment That Confers Lymphoid Specificity
}

\author{
BERNARD MATHEY-PREVOT ${ }^{1}$ AND DAVID BALTIMORE ${ }^{2,3 *}$ \\ Whitehead Institute for Biomedical Research, Cambridge, Massachusetts $02142,{ }^{2}$ Department of Biology, Massachusetts \\ Institute of Technology, Cambridge, Massachusetts $02139,{ }^{3}$ and Dana-Farber Cancer Institute, Boston, \\ Massachusetts $02115^{1}$
}

Received 27 April 1987/Accepted 5 October 1987

\begin{abstract}
The v-abl and v-src oncogenes encode protein-tyrosine kinases that possess different biological properties in spite of their high degree of amino acid conservation. To correlate functional differences with structural domains of the two oncogenes, we recombined $v$-abl and v-src just downstream of the lysines in their ATP-binding sites, within the kinase domain. The biological activity of the chimeric genes was studied and compared with that of $\mathrm{v}$-src and $\mathrm{v}$ - $a b l$. The $\mathrm{v}$-src/v-abl recombinant shared with $\mathrm{v}$-src and $\mathrm{v}$ - $a b l$ the ability to transform fibroblasts. In addition, like v-abl, it transformed lymphoid cells and relieved a hematopoietic cell line of its interleukin 3 requirement. In contrast, the reciprocal construct, $v-a b l / v-s r c$, was transformation defective. Lack of biological activity correlated with formation of a stable complex between the chimeric protein and two cellular proteins and with low kinase activity. We conclude that the specificity within the kinase domain determines the particular biological behavior of protein-tyrosine kinase oncogenes.
\end{abstract}

Protein-tyrosine kinases (PTKs) were first identified as transforming proteins encoded by a class of retroviruses. These viral proteins represent an altered form of cellular enzymes strongly conserved throughout evolution (for a review, see reference 11). Although the biological function of cellular PTKs remains largely unknown, they are suspected of playing a crucial role in signal transduction pathways. One striking feature of these proteins is their high degree of amino acid sequence homology within the kinase domain. Despite this sequence conservation, PTKs display varied biological functions. The functions of growth factor receptors that have cytoplasmic PTK domains, like those for epidermal growth factor, insulin, and platelet-derived growth factor, are obviously different. These functional differences reflect more than their ligand-binding specificity, because platelet-derived and epidermal growth factors trigger quite distinct biochemical responses in cells that have both receptors on their surface (14). That can only be accomplished if the activated receptor kinases display different substrate specificities. Little is known about what sequences in these molecules are involved in directing such specificities, except that they are within the cytoplasmic region.

To address the question of structure-function relationships in these proteins and other tyrosine kinases, we chose the $\mathrm{v}-a b l$ and $\mathrm{v}$-src oncogenes as models. These oncogenes are highly related in amino acid sequences $(26,30,32)$, but have distinct biological properties $(10,17,19,27,29)$. Abelson murine leukemia virus (A-MuLV) (v-abl) transforms both fibroblasts and lymphoid cells in vitro $(27,29)$ and relieves interleukin 3 (IL-3)-dependent cells of their growth factor requirement $(5,19,21,23)$. Rous sarcoma virus (v-src) transforms fibroblasts, but only causes lymphoid transformation and IL-3 independence poorly if at all $(10,17,19,22)$. These differences are clearly a function of the oncogenes proper: placing v-src in a structural configuration resembling that of $\mathrm{v}-a b l$ in A-MuLV failed to duplicate the biological properties of A-MuLV or other viruses carrying the v-abl

\footnotetext{
* Corresponding author.
}

oncogene $(17,19)$. To identify sequences responsible for these biological differences and implicitly responsible for substrate specificity, we recombined v- $a b l$ and v-src just downstream of the lysine in the ATP-binding sites (12), within the kinase domain. The chimeric genes were characterized biochemically and their biological activity was compared with that of v-abl and v-src.

\section{MATERIALS AND METHODS}

Cells, virus, and transfection. Normal and transformed NIH 3T3 fibroblasts were grown in Dulbecco modified Eagle medium with $10 \%$ calf serum. Bone marrow cells, obtained from tibias and femurs of 3-week-old BALB/c mice, were cultured in RPMI medium containing $10 \%$ fetal calf serum and $50 \mu \mathrm{M} \beta$-mercaptoethanol. Ba/F3 cells (19) were grown in RPMI medium with $10 \%$ fetal calf serum and $10 \%$ WEHI-3 cell-conditioned medium (as a source of IL-3). V-SRC virus and Moloney murine leukemia virus (Mo-MuLV) have been described (17). Titers of the various viruses were determined by focus assay on NIH 3T3 cells. Infection of bone marrow cells was performed in liquid cultures as described (27). Transfections and screening of focus formation were done as described (17).

Antisera and protein biochemistry. Tumor-bearing rabbit antiserum (derived against Rous sarcoma virus strain D proteins) $\alpha$-VBII and anti-gag protein antiserum have been described (17). Anti-abl 584 antiserum (33) was a gift from J. Wang. Anti-src monoclonal antibody MAb327 (15) was a gift from J. Brugge. Cell extracts, immunoprecipitations, $\left[{ }^{35} \mathrm{~S}\right]$ methionine labeling, and in vitro kinase reactions were performed as described (18). When warranted, changes in these procedures have been indicated in the text. Glycerol gradients were run by the method of Buss et al. (4). Fractions were collected from the top. Polyacrylamide gel electrophoresis was done by the procedure of Laemmli (13). Gels ( 7.5 or $8.5 \%$ acrylamide) were run at constant voltage.

Mutagenesis and plasmid construction. The point mutation in v-src was obtained by site-directed mutagenesis with a specific oligonucleotide. The 260-base-pair (bp) PstI fragment of $\mathrm{v}$-src, containing the site to be mutated, was sub- 
cloned in M13mp8. The proper orientation of the fragment was ensured by sequencing. The 19-mer oligonucleotide 5'-CCTCCGGGGCCATGGTGCC-3' was obtained from the Whitehead Institute oligonucleotide synthesis facility. Annealing of the oligonucleotide and M13 universal template primer to M13 template containing the PstI fragment and repair-ligation reactions and screening of mutagenized clones were performed as described (37). The T-to-G transversion was confirmed by the creation of a novel $\mathrm{NcoI}$ site within the PstI fragment and independently by sequencing.

pV-SRC ${ }^{\text {nco }}$ plasmid. pV-SRC plasmid DNA (17) was cut with KpnI (unique site in the long terminal repeats [LTRs]). The v-src-containing fragment was cloned in pUC-ABX2 (see below), similarly cut with $K p n I$. This intermediate was then cut with MluI and StuI. These sites are unique in the PstI fragment of v-src used for mutagenesis and lie on either side of the planned mutation $(30,32)$. The M13 clone containing the mutagenized $\mathrm{v}$-src fragment was also cut with MluI and StuI; the small v-src fragment (now containing an NcoI site) was recloned in the doubly digested pUC intermediate (described above) to yield pV-SRC ${ }^{\text {nco }}$ plasmid (see Fig. 2).

pUC-ABX2 plasmid. To create the pUC-ABX2 plasmid (referred as pABX2 in the text), the ABX2 plasmid (25) was modified as follows. Rat sequences flanking the $5^{\prime}$ and $3^{\prime}$ LTRs of ABX2 provirus were trimmed by digesting with $H$ incII (partial) and BstEII (complete). The new ends were converted into an HindIII site $\left(5^{\prime}\right)$ and EcoRI site $\left(3^{\prime}\right)$. The provirus was then subcloned in the polylinker of the pUC13 plasmid (see Fig. 2).

pV-ARC plasmid. pABX2 plasmid DNA was cut with NcoI and HindIII, and the large fragment was isolated. pV-SRC ${ }^{\text {nco }}$ plasmid DNA was similarly cut with $N$ coI and HindIII, and the small v-src-containing fragment was ligated to the large fragment isolated above (see Fig. 2).

pV-SBL plasmid. pV-SRC ${ }^{\text {nco }}$ plasmid DNA was cut with NcoI and HindIII. The larger fragment containing the $5^{\prime}$ half of v-src was isolated. pABX2 was cut with NcoI and
HindIII, and the smaller fragment was ligated to that isolated above (see Fig. 2).

\section{RESULTS}

To identify the sequences that distinguish the biological activity of $\mathrm{v}$ - $a b l$ from that of $\mathrm{v}-s r c$, we created reciprocal recombinants between the two genes and studied how the $\mathrm{v}-a b l$ phenotype segregated in each recombinant. For this purpose, a region just downstream of the lysine in the ATP-binding site of v-abl and v-src was chosen for recombination (Fig. 1). In v-abl, an NcoI site (CCATGG) is present, whereas the corresponding sequence in $\mathrm{v}$-src (based on amino acid alignment) is CCATGT. We used oligonucleotide-directed mutagenesis to make a T-to-G transversion in the above v-src hexamer sequence. This created an NcoI site in $\mathrm{v}$-src and replaced a serine residue with an alanine residue (Fig. 1). The entire v-src gene, containing the mutated fragment, was reconstructed and inserted back into a murine retroviral vector. This construct, $\mathrm{pV}-\mathrm{SRC}^{\mathrm{nco}}$, was cotransfected with helper virus Mo-MuLV plasmid DNA (pZAP) into NIH 3T3 cells, and its activity was compared with that of the wild-type construct, pV-SRC. We observed no differences in efficiency or time of focus appearance. Furthermore, viral stocks prepared from cells transfected with pV-SRC ${ }^{\text {nco }}$ or pV-SRC showed comparable titers (data not shown). The transforming protein detected in $\mathrm{pV}-\mathrm{SRC}^{\text {nco. }}$ transformed cells displayed a high level of in vitro tyrosine kinase activity (see Fig. 4, lane a). It also comigrated with wild-type $160^{\text {v-src }}$ during electrophoresis through a sodium dodecyl sulfate (SDS)-polyacrylamide gel (data not shown).

Because $\mathrm{pV}-\mathrm{SRC} \mathrm{nco}^{\text {nco }}$ was biologically active and behaved identically to pV-SRC, we proceeded with the recombination outlined in Fig. 2. Parental DNAs, pV-SRC ${ }^{\text {nco }}$, and pABX2 were recombined at the NcoI site to yield two reciprocal constructs, $\mathrm{pV}-\mathrm{SBL}$ (src/abl) and pV-ARC $(a b l / s r c)$. These constructs were tested for biological activity on NIH 3T3 cells. DNAs were cotransfected into these cells
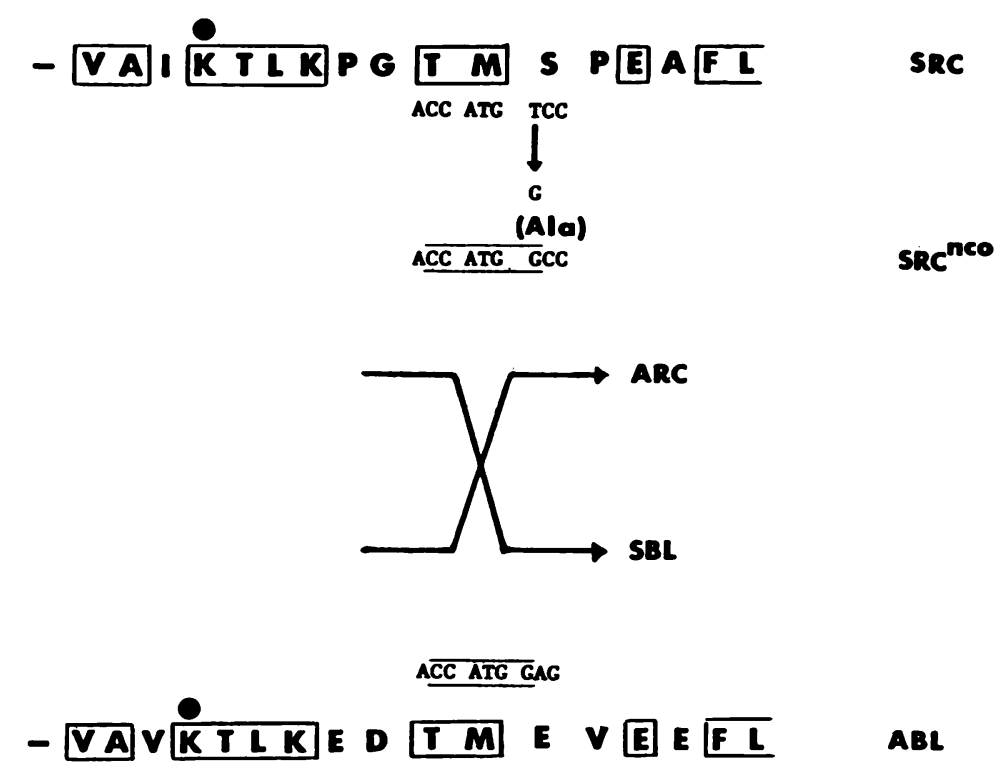

FIG. 1. Strategy of recombination. Amino acid sequence comparison of $v-s r c$ and $v-a b l$ is shown around the region where mutagenesis was targeted. Homologous residues are boxed. The Ncol sequence in v-abl (CCATGG) is indicated. The T-to-G transversion in v-src is indicated. The newly created $\mathrm{NcoI}$ site and serine-to-alanine change in V-SRC ${ }^{\text {co }}$ are diagrammed. The solid circle identifies the lysine residue in the ATP-binding site. Generation of the recombinants between v-abl and v-src ${ }^{\text {nco }}$ is outlined. 

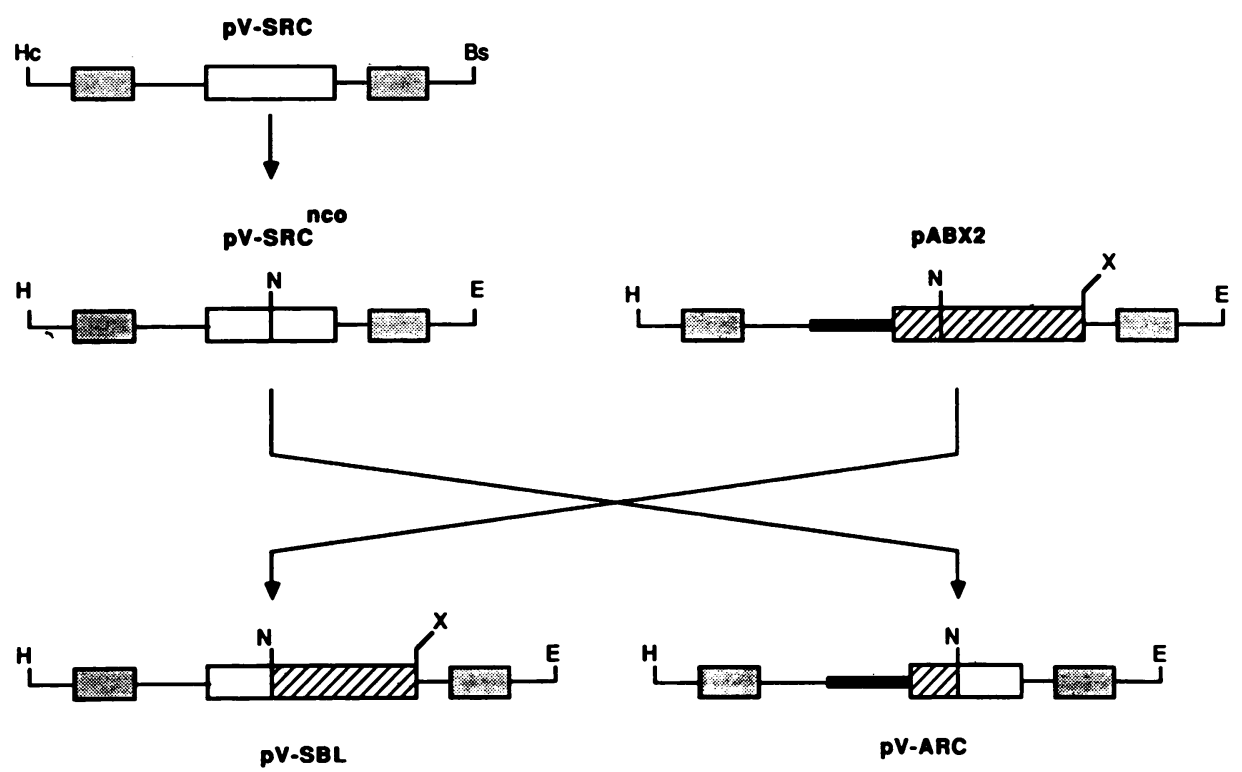

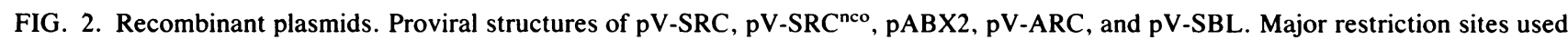
for the cloning and recombination steps are indicated: Bs, BstEII; E, EcoRI; H, HindIII; Hc, HincII; N, NcoI; X, XhoI. Shaded boxes, Mo-MuLV LTRs; open boxes, v-src sequence; hatched boxes, v-abl sequence; thick solid line, A-MuLV-derived gag sequence.

with pZAP DNA (Mo-MuLV helper DNA) and pSV2neo (which confers G418 resistance [31]) DNAs. Two days later, cells were split into two sets; one set was selected in the presence of $\mathrm{G} 418$, and the other was checked for the appearance of foci. Parental DNAs (pV-SRC ${ }^{\text {nco }}$ and $\mathrm{pABX}$ ) were transfected by the same protocol. Foci were observed simultaneously in pV-SRC nco, pABX2, and pV-SBL cultures. We did notice a slight decrease (three- to fivefold) in the number of foci with pV-SBL compared with pABX2 (data not shown). Surprisingly, we detected no foci in pV-ARC cultures. When G418-resistant colonies were scored, we saw equivalent numbers of colonies in $\mathrm{pV}$ $\mathrm{SRC}^{\text {nco }}$ and $\mathrm{pV}$-ARC cultures. A dramatic reduction in number was evident in pABX2 and pV-SBL plates. Whereas the vast majority of $\mathrm{pV}-\mathrm{SRC}{ }^{\text {nco }}$ colonies were transformed (over $90 \%$ ), none of the pABX2 or pV-SBL G418-resistant colonies were. This is usually observed with plasmids that produce A-MuLV and results from a toxic effect of $v$ - $a b l$ on transfected cells (36). Foci seen in unselected cells result from the spread of infectious virus transiently expressed in cells cotransfected with $\mathrm{v}-a b l$ and pZAP plasmid DNAs. These results indicate that, in fibroblasts, $\mathrm{pV}$-SBL behaves similarly to $\mathrm{pABX} 2$, whereas $\mathrm{pV}$-ARC is transformation defective. To examine whether $\mathrm{pV}$-ARC might cause temperature-sensitive transformation, we placed the G418-resistant colonies or unselected cultures at 32 or $39^{\circ} \mathrm{C}$. This had no effect on cell morphology in either set of plates, even after a prolonged incubation of 5 days.

To obtain virus stocks and check for synthesis of the viral chimeric proteins, we obtained cell clones from each of the transfected cultures. pV-SRC nco, pABX2, pV-SBL, and pV-ARC cell clones and uninfected NIH 3T3 cells were then labeled with $\left[{ }^{35} \mathrm{~S}\right]$ methionine, and cell extracts were made. Portions were immunoprecipitated with a battery of specific antisera which recognized gag ( $\alpha$-gag), v-src ( $\alpha$ VBII, MAb327), or v-abl ( $\alpha-584)$ determinants. pV-SBL-directed protein has a predicted molecular mass of 89 kilodaltons $(\mathrm{kDa})$, consisting of $\mathrm{v}$-src and $\mathrm{v}-a b l$ sequences. pV-ARCencoded protein contains $g a g, \mathrm{v}-a b l$, and $\mathrm{v}-\operatorname{src}$ sequences and has a predicted molecular mass of $68 \mathrm{kDa}$. When extracts were immunoprecipitated with $\alpha$-gag antiserum, viral gag precursor Pr65 gag polyprotein, encoded by helper virus Mo-MuLV, was detected in all of the transfected

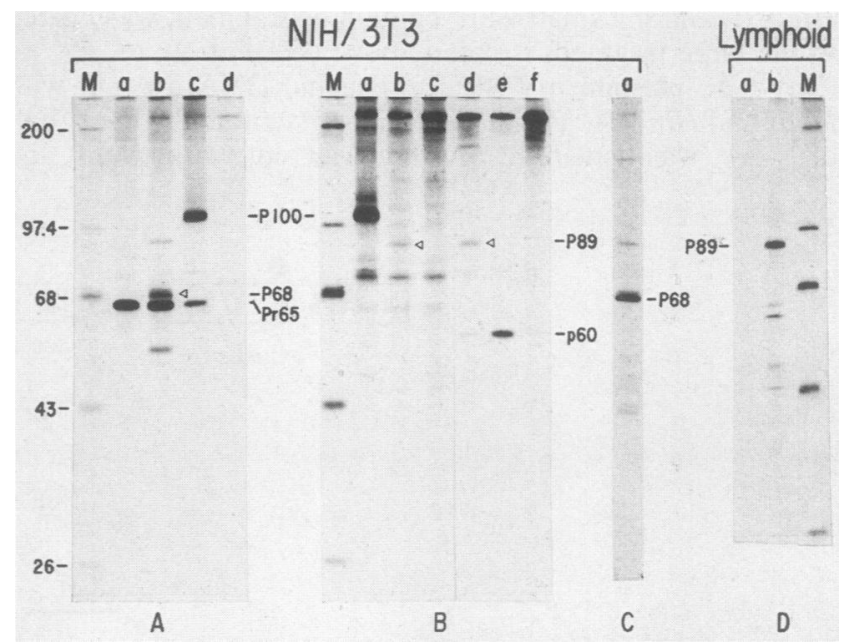

FIG. 3. Protein characterization. NIH 3T3 cell clones (A, B, C) or lymphoid cells (D) were labeled with ${ }^{35}$ S $]$ methionine for $4 \mathrm{~h}$. Equal amounts of trichloroacetic acid (TCA)-precipitable counts from the labeled cell extracts were immunoprecipitated with various antisera, and immune complexes were separated by electrophoresis through an $8.5 \%$ polyacrylamide-SDS gel. (A) $\alpha$-gag antiserum. Lanes: a, pV-SRC ${ }^{\text {nco }}$ cells; b, pV-ARC cells; c, pABX2 cells; d, uninfected cells. (B) $\alpha-584 \alpha-a b l$ antiserum (lanes a to c) and MAb327 $\alpha$-src monoclonal (lanes d to f). Lanes: a, pABX2 cells; $b$ and d, pV-SBL cells; $c$ and $f$; uninfected cells; $e, p V-S R C^{\text {nco }}$ cells. (C) $\alpha$ VBII $\alpha$-src antiserum. Lanes: a, pV-ARC cells. (D) $\alpha$-gag antiserum (lane a) and MAb327 $\alpha$-src monoclonal (lane b). pV-SBL cells. Lanes M, Marker lanes; the same set of markers was used in panels A, B, and D. Open arrowhead points to the protein of interest in the different lanes. Sizes are indicated to the left of panel A (in kilodaltons). 
clones (Fig. 3A, lanes a, b, and c). As expected, a protein of 100 $\mathrm{kDa}, \mathrm{P} 100^{\text {gag-abl }}$, was observed in pABX2-transformed cells (lane $\mathrm{c}$ ). In $\mathrm{pV}$-ARC cells, the expected $68-\mathrm{kDa}$ protein was detected, but three other proteins were also evident (lane b). The strongly reactive protein of $58 \mathrm{kDa}$ was recognized by $\alpha$-gag antiserum but not by $\alpha$-src antiserum (Fig. 3C). It may represent some gag intermediate, but its exact identity is at present unclear. The two other proteins (better seen in Fig. 5) were 90 and $50 \mathrm{kDa}$ in mass (faint in this figure). These proteins were also observed when $\alpha$-VBII was used (Fig. 3C). In all likelihood, they are the two cellular proteins, hsp90 and p50, previously described as forming a specific Complex with $\mathrm{p}^{60^{\mathrm{v}-s r c}}$ and some other src-related proteins (2). Evidence for such a complex with the pV-ARCencoded protein, $\mathrm{P} 68^{\text {arc }}$, is provided below.

The same extracts were reacted with $\alpha-a b l$ antiserum (Fig. $3 \mathrm{~B}$, lanes a to c) or MAb327 ( $\alpha$-src) (lanes d to f). P100 gag-abl was readily detected, as well as its glycosylated form (35), which runs more slowly (lane a; also seen in lane c, Fig. 3A). In pV-SBL-transformed cells, we observed a protein with the expected size of $89 \mathrm{kDa}$ (lane b). This protein was also recognized by MAb327 (lane d), but was not detected with either antiserum in uninfected NIH 3T3 cells (lanes $c$ and $f$ ). These properties are in agreement with the expected behavior of the transforming protein encoded by pV-SBL, P89sbl. Finally, when pV-SRC ${ }^{\text {nco }}$ cell extracts were immunoprecipitated with MAb327 (lane e), the expected 60-kDa v-src protein was detected. The $60-\mathrm{kDa}$ protein in lanes $\mathrm{d}$ and $\mathrm{f}$ (partel B) and in lane b (panel D) represents endogenous mouse c-src protein.

To test whether the viral chimeric proteins exhibited PTK activity, extracts from unlabeled cell clones were immunoprecipitated and immune complexes were assayed for in vitro kinase activity. Transforming proteins of $\mathrm{pV}-\mathrm{SRC}^{\mathrm{nco}}$, pABX2, and pV-SBL were all autophosphorylated in this assay (Fig. 4). The phosphoprotein migrating at about 125 $\mathrm{kDa}$ in lane a was consistently detected in association with p60 ${ }^{\text {v-src }}$ when MAb327 was used for immunoprecipitation. Although probably a cellular protein, its nature has not been

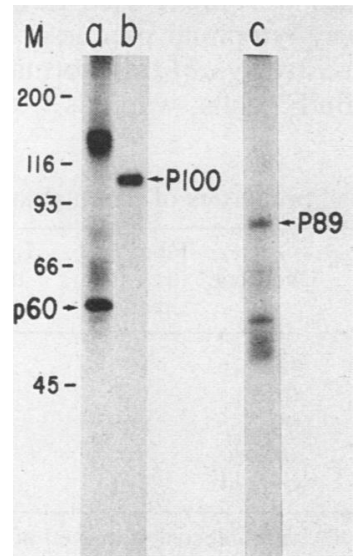

FIG. 4. In vitro kinase activity. Cell extracts containing equal amount of protein were immunoprecipitated with $\alpha$-gag (lane b) or MAb327 $\alpha$-src (lanes a and c). Immune complexes were washed and suspended in kinase buffer and incubated for $20 \mathrm{~min}$ at $25^{\circ} \mathrm{C}$. The reaction was stopped by adding Laemmli sample buffer (13). Samples were electrophoresed through an $8.5 \%$ polyacrylamide-SDS gel, and phosphoproteins were visualized after autoradiography of the dried gel. Lanes: a, pV-SRC ${ }^{\text {nco }}$ NIH 3T3; b, pABX2 NIH 3T3; c, pV-SBL NIH 3T3. M, Standards (in kilodaltons) and the transforming proteins are indicated.

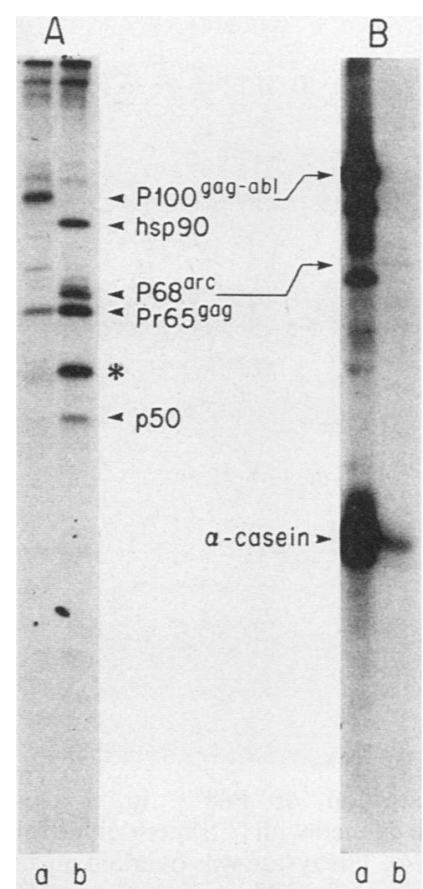

FIG. 5. Quantitation of kinase-specitic activity. NIH 3T3 cells $\left(7.5 \times 10^{5}\right)$, infected with V-ARC or ABX2 virus, were labeled with $400 \mu \mathrm{Ci}$ of $\left[{ }^{35} \mathrm{~S}\right]$ methionine. Incorporation in the protein extracts were monitored by TCA precipitation and counting. Portions of each lysate containing equal amounts of TCA-precipitable counts were immunoprecipitated with excess anti-gag antiserum. The immune complexes were either directly separated on a $10 \%$ polyacrylamide-SDS gel (A) or incubated as described in the legend to Fig. 4 in kinase buffer containing $\alpha$-casein $(0.3 \mathrm{mg} / \mathrm{ml})$ prior to electrophoresis (B). Lanes: a, ABX2 NIH 3T3 cells; b, V-ARC NIH 3T3 cells. Phosphoproteins in panel B were visualized after autoradiography of a dried gel that had been covered with two layers of aluminum foil to block the contribution of $\left[{ }^{35} S\right]$ methionine radiation emitted by P68 arc and P100sag-abl. The $\alpha$-casein band was excised from the gel, and ${ }^{32} \mathrm{P}$ incorporation was quantitated in scintillation fluid. *, 58-kDa "gag"-related protein.

investigated further. For the pV-ARC extracts, very little radioactivity was detected in association with $\mathrm{P} 8^{\text {arc }}$ (data not shown).

The apparently very low kinase activity of $\mathrm{P} 68^{\text {arc }}$ could explain the failure of $\mathrm{V}$-ARC virus to transform fibroblasts. To investigate its activity more precisely, V-ARC- and ABX2-infected fibroblasts were labeled for $18 \mathrm{~h}$ with $\left[{ }^{35} \mathrm{~S}\right]$ methionine, and levels of P68 ${ }^{\text {arc }}$ and P100sag-abl were analyzed after immunoprecipitation with anti-gag antiserum (Fig. 5A). Because we detected similar amounts of both proteins after this long labeling period, we could exclude the possibility that $\mathrm{P} 68^{\text {arc }}$ expression was too low to achieve transformation of fibroblasts. When P100gag-abl and P68 ${ }^{a r c}$, immunoprecipitated from identical portions of the lysates shown in Fig. 5A, were compared for their ability to phosphorylate in vitro the exogenous substrate $\alpha$-casein, P68 ${ }^{\text {arc }}$ showed 23-fold lower activity (Fig. 5B). A 26-fold lower activity was measured when enolase was used as a substrate (data not shown). Thus, the defectiveness of $\mathrm{V}$-ARC virus is best explained by the low specific PTK activity of P68 ${ }^{\text {arc }}$.

As noticed previously, $\mathrm{P} 68^{\text {arc }}$ was recovered in association with two cellular proteins presumed to be hsp90 and p50. To determine what proportion of P68 ${ }^{a r c}$ was in such a complex, pV-ARC cells were labeled with $\left[{ }^{35} \mathrm{~S}\right]$ methionine 


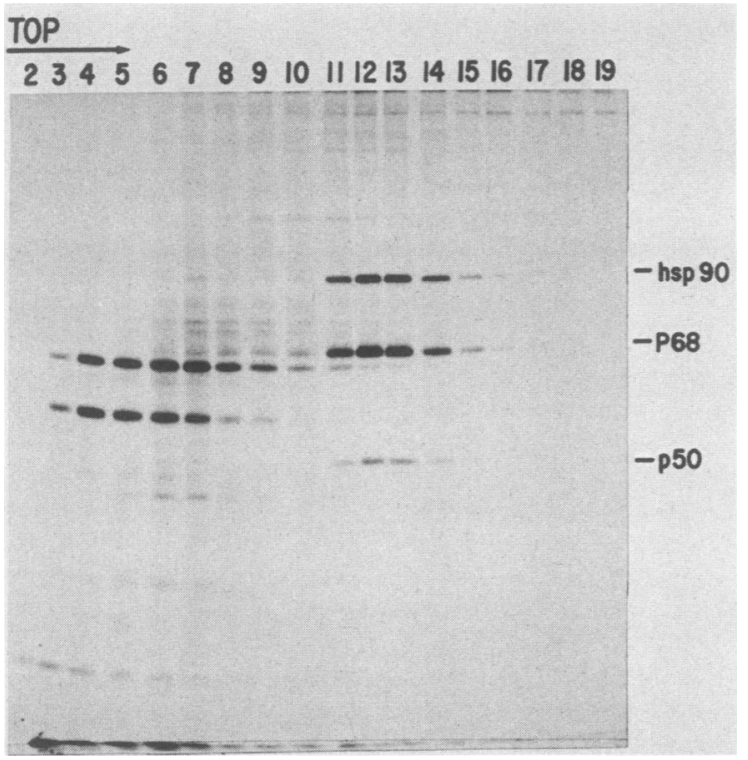

FIG. 6. Demonstration of $\mathrm{P} 68^{\text {arc }}$ in a complex. pV-ARC $\mathrm{NIH} / 3 \mathrm{~T} 3$ cells were labeled with $\left[{ }^{35} \mathrm{~S}\right]$ methionine for $14 \mathrm{~h}$. Cells were lysed and clarified (4). The lysate was overlaid on a 5 to $20 \%$ glycerol gradient and centrifuged for $19 \mathrm{~h}$ at $40,000 \mathrm{rpm}(150,000 \times \mathrm{g})$ at $4^{\circ} \mathrm{C}$ in a Beckman SW50.1 rotor. Gradient fractions $(0.2 \mathrm{ml})$ were collected from the top. The two labeled proteins in fractions 3 to 11 represent Pr65 ${ }^{g a g}$ and a gag-related 58-kDa protein. The two cellular proteins and $\mathrm{P} 68^{\text {arc }}$ are indicated.

for $14 \mathrm{~h}$, and a clarified lysate was centrifuged through a glycerol gradient. Fractions were collected and analyzed by SDS-polyacrylamide gel electrophoresis after immunoprecipitation with $\alpha$-gag antiserum (Fig. 6). The free form of P68 ${ }^{\text {arc }}$ would be found in the same fractions as Pr658ag and the "gag-related" 58-kDa proteins which migrate as monomers. It is clear from this analysis, however, that P68 protein did not sediment as a monomer; rather, the majority sedimented as a much larger species and cosedimented with $50-$ and $90-\mathrm{kDa}$ proteins. Thus, nearly all of $\mathrm{P} 68^{\text {arc }}$ was bound up in a complex with the two cellular proteins hsp90 and p50. Interestingly, we were unable to detect P100sag-abl, even transiently, in a similar complex (data not shown).

As a final biochemical characterization of the chimeric proteins, we examined their divalent cation requirement in the in vitro kinase reaction. Immune complexes containing the $\mathrm{pV}$-SRC, $\mathrm{pV}-\mathrm{SRC}^{\mathrm{nco}}, \mathrm{pABX} 2$, or $\mathrm{pV}-\mathrm{SBL}$ transforming protein were suspended in kinase buffer containing either 10 $\mathrm{mM} \mathrm{Mg}^{2+}, 10 \mathrm{mM} \mathrm{Mn}{ }^{2+}$, or no divalent cations. Very little activity was detected (less than $1 \%$ ) for all proteins in the absence of divalent cations (data not shown). p60 ${ }^{\mathrm{v}-s r c}$, encoded by $\mathrm{pV}$-SRC, demonstrated a slight preference for $\mathrm{Mn}^{2+}$ over $\mathrm{Mg}^{2+}$ in this assay (Table 1). Surprisingly, $\mathrm{p} 60^{\mathrm{v}-\text { src }}$ encoded by $\mathrm{pV}-\mathrm{SRC} \mathrm{n}^{\mathrm{nco}}$ showed a marked preference for $\mathrm{Mn}^{2+}$. This difference is probably a consequence of the fact that the mutation introduced in $\mathrm{pV}-\mathrm{SRC}^{\mathrm{nco}}$ is so close to the ATP-binding site (Fig. 1). Likewise, P89sbl showed higher activity when $\mathrm{Mn}^{2+}$ was present in the assay. P100 ${ }^{\text {ag }}-\mathrm{abl}$ also preferred $\mathrm{Mn}^{2+}$, but the difference was not as marked (Table 1).

To examine the effects of the various viruses on lymphoid and $\mathrm{Ba} / \mathrm{F} 3$ cells (Table 2), we obtained virus stocks from the various cell clones. V-SRC ${ }^{\text {nco }}, \mathbf{A B X} 2$, and V-SBL viruses were all transforming, having titers from $5 \times 10^{5}$ to $10^{6}$ focus-forming units per ml (data not shown). V-ARC virus,
TABLE 1. Cation preference of viral kinases ${ }^{a}$

\begin{tabular}{lccc}
\hline \multirow{2}{*}{ Virus } & \multirow{2}{*}{ Protein } & \multicolumn{2}{c}{$\%$ of maximal activity } \\
\cline { 3 - 4 } & & $\mathrm{Mg}^{2+}$ & $\mathrm{Mn}^{2+}$ \\
\hline ABX2 & $\mathrm{P} 100$ & 49 & 100 \\
V-SRC & $\mathrm{p} 60$ & 80 & 100 \\
V-SRC & $\mathrm{p} 60$ & 16 & 100 \\
V-SBL & $\mathrm{P} 89$ & 11 & 100 \\
\hline
\end{tabular}

${ }^{a}$ Immunoprecipitates containing the indicated proteins were assayed for PTK activity in vitro. Samples were suspended in kinase buffer $(50 \mathrm{mM}$ HEPES [ $\mathrm{pH} 7.4], 10 \mathrm{mM} \mathrm{Mg}\left(\mathrm{CH}_{3} \mathrm{CO}_{2}\right)_{2}$ or $\mathrm{MnCl}_{2}, 0.7 \mu \mathrm{M}\left[\gamma^{-32} \mathrm{P}\right] \mathrm{ATP}, 5 \%$ glycerol) and incubated for $20 \mathrm{~min}$ at $25^{\circ} \mathrm{C}$. After autoradiography, gel bands containing the phosphoproteins were excised and counted. Results are given as percentage of maximal activity obtained. P100 $0^{\text {gag-abl }}$ was immunoprecipitated with $\alpha$-gag antiserum; p60 immunoprecipitated with MAb327.

as expected, was transformation defective on fibroblasts, but the V-ARC genome was passed at good efficiency, as measured by expression of the predicted protein in freshly infected cells (data not shown).

To study the effect of these viruses on bone marrow cell transformation, cells collected from the femurs and tibias of 3-week-old mice were infected in liquid cultures with each viral stock, as well as with Mo-MuLV and V-SRC viruses. V-ARC and Mo-MuLV viruses had no effect on the bone marrow cultures. V-SRC and V-SRC ${ }^{\text {nco }}$ viruses caused a transient burst of proliferation in the infected cultures. We were unable, however, to recover any transformed cells, even 3 months after infection and cultivation of the cells over a bone marrow-derived feeder layer. ABX2 and V-SBL viruses, by contrast, elicited continuous proliferation of suspension cells at equal efficiency. Transformed cells were established in the absence of feeder cells 3 weeks after infection. We confirmed that cells transformed with V-SBL virus synthesized $\mathrm{P} 89^{\text {sbl }}$ protein (Fig. 3D, lane b). We also found that these cells had rearranged their immunoglobulin genes in a configuration typical of pre-B cells (8) (data not shown). Thus, in this assay, $\mathrm{V}-\mathrm{SBL}$ virus behaved identically to $\mathrm{ABX} 2$ virus.

The above viruses were next used to infect $\mathrm{Ba} / \mathrm{F} 3$ cells. These cells are early lymphoid precursor cells that require IL-3 for growth in vitro. v-abl transformation confers IL-3 independence on $\mathrm{Ba} / \mathrm{F} 3$ cells, whereas $\mathrm{v}$-src transformation

TABLE 2. Biological properties of parental and chimeric viruses

\begin{tabular}{lllccl}
\hline Virus & Protein & Oncogene & $\begin{array}{c}\text { Fibroblast } \\
\text { transfor- } \\
\text { mation }\end{array}$ & $\begin{array}{c}\text { Lymphoid } \\
\text { transfor- } \\
\text { mation }^{a}\end{array}$ & $\begin{array}{l}\text { IL-3 inde- } \\
\text { pendence }^{b}\end{array}$ \\
\hline ABX2 & P100 & $a b l$ & Yes & Yes & Yes \\
V-SRC & p60 & $s r c$ & Yes & No & Partial $^{c}$ \\
V-SRC & p60 & $s r c$ & Yes & No & Partial $^{c, d}$ \\
V-ARC & P68 & $a b l / s r c$ & No & No & No \\
V-SBL & P89 & srclabl & Yes & Yes & Yes \\
\hline
\end{tabular}

a $10^{6}$ bone marrow cells were infected with $1 \mathrm{ml}$ of virus in liquid culture (26). Cells were monitored for 3 months. Suspension cells were taken periodically off the bone marrow-derived feeder layer and tested for their ability to become established. V-SBL and ABX2 cultures were established 3 weeks after infection.

${ }^{b} 10^{6} \mathrm{Ba} / \mathrm{F} 3$ cells were infected with $1 \mathrm{ml}$ of virus as described (19). Proliferation of cells was monitored 4 days after the infected cells were placed in medium without IL-3, and continuous growth was monitored over the next week.

c IL-3 was necessary for continuous growth, but the requirement was reduced compared with uninfected cells.

${ }^{d}$ Lower amounts of IL-3 were required for growth compared with V-SRC cultures. 
only lowers the IL-3 requirement of these cells (19). Two days after infection with the various stocks, $\mathrm{Ba} / \mathrm{F} 3$ cells were placed in medium lacking IL-3. Proliferation of the mass cultures was assessed 4 days later. At that time, no surviving cells could be observed in Mo-MuLV and V-ARC cultures. In contrast, cells infected with $\mathrm{ABX} 2$ or $\mathrm{V}$-SBL viruses were actively proliferating and looked very healthy. In both cases, cells became totally IL-3 independent. Again, we were unable to distinguish the biological effect of V-SBL and $\mathrm{ABX} 2$ viruses.

Cells infected with V-SRC ${ }^{\text {nco }}$ virus behaved less well than the latter cultures, but some proliferation was observed. After several days in culture, the cell appearance worsened and significant cell death was observed. These effects were readily reversed by addition of a small amount of IL-3. The same situation occurred with V-SRC virus, although the cells did not do nearly as well as with $\mathrm{V}-\mathrm{SRC} \mathrm{n}^{\text {nco }}$ virus. The slight difference in behavior between the two viruses was not studied further. The results of the various assays with the viruses are summarized in Table 2.

\section{DISCUSSION}

$\mathrm{v}-a b l$ and $\mathrm{v}$-src oncogenes, despite their high amino acid sequence homology, elicit different biological effects. This is best illustrated by lymphoid transformation and abrogation of IL-3 requirement in cell lines dependent on it for growth in vitro. Both effects are mediated by $\mathrm{v}-a b l$, but neither is mediated by v-src $(17,19)$. However, both oncogenes are very efficient at transforming fibroblasts $(10,17,29)$. To better understand and compare these differences, we have produced viruses carrying chimeric v-alb/v-src or v-src/v-abl genes. For lack of precise structural knowledge to direct the site of recombination, we selected an approach that allowed easy and precise recombination. This led us to create a restriction site in $\mathrm{v}$-src at a position homologous to a site already present in $\mathrm{v}-a b l$. It required a single nucleotide replacement in a hexamer sequence just downstream of the lysine of the ATP-binding site in $\mathrm{p}^{60^{\mathrm{v}-s r c}}$ (12). The single amino acid change (serine to alanine) did not affect the biological activity of v-src. It did, however, modify the divalent cation usage of the mutant $\mathrm{p} 60^{\mathrm{v}-s r c}$ in the in vitro kinase reaction.

The concept of a kinase domain within the PTK genes and proteins derives from two sources: the high sequence homology displayed among the PTKs within a subregion of their individual sequences, and the direct demonstration of kinase activity in a $30-\mathrm{kDa}$ subfragment of $\mathrm{v}$-src $(1,7$; our observation). One landmark near the $\mathrm{N}$-terminal end of the kinase domain is the lysine that interacts with ATP (12). By recombining $v$-src and $v$-abl downstream of this lysine, we ensured that $\mathrm{V}$-ARC received the majority of its kinase from $\mathrm{v}$-src and $\mathrm{V}$-SBL received the equivalent region from $\mathrm{v}$ - $a b l$. They received about 40 and $30 \mathrm{kDa}$, respectively, of the $\mathrm{N}$-terminal amino acid sequence from the other partner. This sequence contains regions of $\mathrm{v}-\mathrm{src} / \mathrm{v}-\mathrm{abl}$ homology but is much less homologous than the kinase region and might have been thought to encode the transformation specificity.

The virus carrying the v-src/v-abl oncogene, V-SBL, behaved biologically like ABX2 virus (or A-MuLV). It transformed fibroblasts and lymphoid cells in vitro and rendered $\mathrm{Ba} / \mathrm{F} 3$ cells $\mathrm{IL-3}$ independent. The efficiency of $\mathrm{V}-\mathrm{SBL}$ and $\mathrm{ABX} 2$ viruses in eliciting these effects was similar, but a small decrease in focus formation after transfection of pV-SBL DNA was noted.

Thus, the v-abl sequence present in V-SBL virus appears to induce effects usually ascribed to the entire v-abl se- quence. Unfortunately, the behavior of V-ARC virus was not reciprocal to that of V-SBL; rather, V-ARC virus was transformation defective. This lack of transformation correlated with two biochemical findings. V-ARC protein had very low specific kinase activity, and the majority of the protein was recovered as a complex with two cellular proteins, hsp90 and p50 (2). The reason for the complex formation is not known. Perhaps the two cellular proteins recognize in $\mathrm{P} 8^{\text {arc }}$ an unproperly folded molecule and sequester it, in a complex, away from the plasma membrane. Alternatively, P68 arc protein may lack sequences normally involved in releasing p $60^{\mathrm{v}-s r c}$ from the complex with p50 and hsp90. We tested this possibility by replacing the gag sequences of P68 arc with the first 110 amino acids of $\mathrm{p} 60^{\mathrm{v}-s r c}$. The gag and N-terminal src sequences had been shown previously to be interchangeable in chimeric constructs (17). This replacement, however, failed in releasing the new chimeric protein from its complex. It also resulted in a transformation-defective protein with low kinase activity (data not shown). Also unresolved is the reason for the low kinase activity of P68 ${ }^{\text {arc }}$. It could be either an intrinsic enzymatic defect or the consequence of sequestration of the protein in a complex. Previously, it had been reported that the kinase activity of $\mathbf{p} 60^{\mathrm{v}-s r c}$ complexed to p50 and hsp90 is significantly reduced $(3,6)$, but this view has recently been challenged (9).

Regardless of these open questions, our results demonstrate two significant points. Despite the lack of relevant information about the three-dimensional structure of $\mathrm{p}^{\mathrm{v}} \mathrm{0}^{\mathrm{v}-\mathrm{src}}$ or P100sag-abl to suggest a recombination site, we did succeed in creating a functional chimeric protein. One of the products of the v-src/v-abl recombination, P89 ${ }^{s b l}$, was both enzymatically and biologically active. This success underscores the relatedness of $\mathrm{v}$-src and $\mathrm{v}-a b l$.

These experiments show that induction of IL-3 independence and transformation of lymphoid cells both correlate with the sequences common between V-SBL and ABX2 viruses, mainly the PTK domain. The fact that $\mathrm{V}$-ARC virus is transformation defective is noninformative in this respect. Recently, Privalsky (24) fused the first $119 \mathrm{~N}$-terminal amino acids of v-erbB to amino acids 226 to 526 of v-src. The chimeric gene induced fibroblast transformation and expressed a hybrid protein with biochemical characteristics similar to those of v-src (24). The chimera failed, however, in transforming erythroid cells. Thus, target cell specificity of $\mathrm{v}$-src was not influenced by the v-erbB sequence present in the hybrid. Erythroid transformation therefore appears to require $v$-erbB sequences encoded in the kinase domain of this oncogene.

The common sequences between $\mathrm{V}-\mathrm{SBL}$ and $\mathrm{ABX} 2$ viruses do extend downstream of the v-src homology in v-abl. These additional sequences are not in the kinase domain proper and might also contribute to the biological properties of these viruses. In fact, the region downstream of the kinase domain of $\mathrm{v}-a b l$ in $\mathrm{A}-\mathrm{MuLV}$ has been linked in vitro to enhanced lymphoid transforming ability by this virus and in vivo to enhanced tumorigenicity (28). This finding does not, however, indicate that sequences beyond the PTK domain are necessary for lymphoid transformation, because certain variants of an A-MuLV strain which lack most of these $3^{\prime}$ sequences, although crippled in their ability to transform lymphoid cells in vitro, can induce lymphomas in vivo with an efficiency comparable to that of wild-type A-MuLV (20). Even though important interactions are likely to be mediated by this sequence, the region appears to serve as a modulator of the intrinsic biological properties of the $\mathrm{v}-a b l$ kinase 
domain. The existence of complex interactions within the $v-a b l$ sequences should not obscure the main conclusion of these experiments: the transformation specificity of a viral PTK has been localized to a region that is coincident with the center of catalytic activity, implying that it is probably catalytic specificity which determines transformation specificity.

\section{ACKNOWLEDGMENTS}

We thank Joan Brugge for her generous gift of MAb327 antiserum and Jean Wang for anti-abl 584 antiserum.

This work was supported by Public Health Service program project grant CA-38497 from the National Cancer Institute. B.M.-P. was supported by a Helen Hay Whitney fellowship.

\section{LITERATURE CITED}

1. Brugge, J., and D. Darrow. 1984. Analysis of the catalytic domain of the phosphotransferase activity of two avian sarcoma virus transforming proteins. J. Biol. Chem. 259:4550-4557.

2. Brugge, J. S., E. Erikson, and R. L. Erikson. 1981. The specific interaction of the Rous sarcoma virus transforming protein, pp60 ${ }^{\text {v-src }}$, with two cellular proteins. Cell 25:363-372.

3. Brugge, J. S., W. Yonemoto, and D. Darrow. 1983. Interaction between the Rous sarcoma virus transforming protein and two cellular phosphoproteins: analysis of the turnover and distribution of this complex. Mol. Cell. Biol. 3:9-19.

4. Buss, J. E., M. P. Kamps, and B. M. Sefton. 1984. Myristic acid is attached to the transforming protein of Rous sarcoma virus during or immediately after synthesis and is present in both soluble and membrane-bound forms of the protein. Mol. Cell. Biol. 4:2697-2704.

5. Cook, W. D., D. Metcalf, N. A. Nicola, A. W. Burgess, and F. Walker. 1985. Malignant transformation of a growth factordependent myeloid cell line by Abelson virus without evidence of an autocrine mechanism. Cell 41:677-683.

6. Courtneidge, S. A., and J. M. Bishop. 1982. Transit of pp60v-src to the plasma membrane. Proc. Natl. Acad. Sci. USA 79:71177121.

7. Cross, F. R., E. A. Garber, and H. Hanafusa. 1985. N-terminal deletions in Rous sarcoma virus p60 ${ }^{\text {src }}$ : effects on tyrosine kinase and biological activities and on recombination in tissue culture with the cellular src gene. Mol. Cell. Biol. 5:2789-2795.

8. DePinho, R., K. Kruger, N. C. Andrews, S. Lutzger, D. Baltimore, and F. W. Alt. 1984. The molecular basis of heavy-chain class switching and switch region deletion in an Abelson virustransformed cell line. Mol. Cell. Biol. 4:2905-2910.

9. Garber, E. A., B. J. Mayer, R. Jove, and H. Hanafusa. 1987. Analysis of $\mathrm{p}^{\mathrm{v}} \mathrm{0}^{\mathrm{v}-\mathrm{src}}$ mutants carrying lesions involved in temperature sensitivity. J. Virol. 61:354-360.

10. Hanafusa, H. 1977. Cell transformation by RNA tumor viruses, p. 401-483. In H. Fraenkel-Conrat and R. R. Wagner (ed.), Comprehensive virology, vol. 10. Plenum Publishing Corp., New York.

11. Hunter, T., and J. A. Cooper. 1985. Protein-tyrosine kinases. Annu. Rev. Biochem. 54:897-930.

12. Kamps, M. P., S. S. Taylor, and B. M. Sefton. 1984. Direct evidence that oncogenic tyrosine kinases and cyclic AMPdependent protein kinase have homologous ATP-binding sites. Nature (London) 310:589-592.

13. Laemmli, U. K. 1970. Cleavage of structural proteins during the assembly of the head of bacteriophage T4. Nature (London) 227:680-685.

14. Leoff, E. B., J. J. Van Wyke, E. J. O'Keefe, and W. J. Pledger. 1983. EGF is required only during the traverse of early $\mathrm{Gl}$ in PDGF stimulated density arrested BALB/c-3T3. Exp. Cell. Res. 147:202-208.

15. Lipsich, L. A., A. J. Lewis, and J. S. Brugge. 1983. Isolation of monoclonal antibodies that recognize the transforming proteins of avian sarcoma viruses. J. Virol. 48:352-360.

16. Maniatis, T., E. F. Fritsch, and J. Sambrook. 1982. Molecular cloning: a laboratory manual. Cold Spring Harbor Laboratory, Cold Spring Harbor, N.Y.
17. Mathey-Prevot, B., and D. Baltimore. 1985. Specific transforming potential of oncogenes encoding protein-tyrosine kinases. EMBO J. 4:1769-1774.

18. Mathey-Prevot, B., H. Hanafusa, and S. Kawai. 1982. A cellular protein is immunologically crossreactive and functionally homologous to the Fujinami sarcoma virus transforming protein. Cell 28:897-906.

19. Mathey-Prevot, B., G. Nabel, R. Palacios, and D. Baltimore. 1986. Abelson virus abrogation of interleukin-3 dependence in a lymphoid cell line. Mol. Cell. Biol. 6:4133-4135.

20. Murtagh, K., G. Skladany, J. Hoag, and N. Rosenberg. 1986. Abelson murine leukemia virus variants with increased oncogenic potential. J. Virol. 60:599-606.

21. Oliff, A., O. Agranovsky, M. D. McKinney, v. V. V. S. Murty, and R. Bauchwitz. 1985. Friend murine leukemia virus-immortalized myeloid cells are converted into tumorigenic cell lines by Abelson leukemia virus. Proc. Natl. Acad. Sci. USA 82:33063310.

22. Pierce, J. H., S. A. Aaronson, and S. M. Anderson. 1984. Hematopoietic cell transformation by a murine recombinant retrovirus containing the $s r c$ gene of Rous sarcoma virus. Proc. Natl. Acad. Sci. USA 81:2374-2378.

23. Pierce, J. H., P. P. Di Fiore, S. A. Aaronson, M. Potter, J. Pumphrey, A. Scott, and J. H. Ihle. 1985. Neoplastic transformation of mast cells by Abelson-MuLV: abrogation of IL-3 dependence by a nonautocrine mechanism. Cell 41:685-693.

24. Privalsky, M. L. 1987. Analysis of the biochemical and biological properties of a v-erbB/src fusion polypeptide. J. Virol. 61: 1938-1948.

25. Prywes, R., J. Hoag, N. Rosenberg, and D. Baltimore. 1985. Protein stabilization explains the gag requirement for transformation of lymphoid cells by Abelson murine leukemia virus. J. Virol. 54:123-132.

26. Reddy, E. P., M. J. Smith, and A. Srinivasan. 1983. Nucleotide sequence of Abelson murine leukemia virus genome: structure similarity of its transforming gene product to other onc gene products with tyrosine-specific kinase activity. Proc. Natl. Acad. Sci. USA 80:3625-3629.

27. Rosenberg, N., D. Baltimore, and C. D. Scher. 1975. In vitro transformation of lymphoid cells by Abelson murine leukemia virus. Proc. Natl. Acad. Sci. USA 72:1932-1936.

28. Rosenberg, N., D. R. Clark, and O. N. Witte. 1980. Abelson murine leukemia virus mutants deficient in kinase activity and lymphoid cell transformation. J. Virol. 36:766-774.

29. Scher, C. D., and R. Siegler. 1975. Direct transformation of 3T3 cells by Abelson murine leukemia virus. Nature (London) 253: 729-731.

30. Schwartz, D. E., R. Tizard, and W. Gilbert. 1983. Nucleotide sequence of Rous sarcoma virus. Cell 32:853-869.

31. Southern, P. J., and P. Berg. 1982. Transformation of mammalian cells to antibiotic resistance with a bacterial gene under control of the SV40 early region promoter. J. Mol. Appl. Genet. 1:327-342.

32. Takeya, T., and H. Hanafusa. 1982. Structure and sequence of the viral and cellular src gene of chickens. I. Complete nucleotide sequence of an EcoRI fragment of recovered avian sarcoma virus which codes for $\mathrm{gp} 37$ and pp60 $0^{\text {src }}$. J. Virol. 44:1-11.

33. Wang, J. Y. J. 1985. Isolation of antibodies for phosphotyrosine by immunization with a v-abl oncogene-encoded protein. Mol. Cell. Biol. 5:3640-3643.

34. Wang, J. Y. J., and D. Baltimore. 1985. Localization of tyrosine kinase-coding region in $\mathrm{v}$ - $\mathrm{abl}$ oncogene by the expression of v-abl-encoded proteins in bacteria. J. Biol. Chem. 260:64-71.

35. Watanabe, S. M., N. Rosenberg, and O. N. Witte. 1984. A membrane-associated, carbohydrate-modified form of the v-abl protein that cannot be phosphorylated in vivo or in vitro. J. Virol. 51:620-627.

36. Ziegler, S. F., C. A. Whitlock, S. P. Gofi, A. Gifiord, and O. N. Witte. 1981. Lethal effect of the Abelson murine leukemia virus transforming gene product. Cell 27:477-486.

37. Zoller, M. J., and M. Smith. 1984. Oligonucleotide-directed mutagenesis: a simple method using two oligonucleotide primers and a single-stranded DNA template. DNA 3:479-488. 